\title{
The Philosophical Discourse of the Enlightenment: Totalitarian Ethics or Relativist Politics?
}

\author{
Ramzi B. Mohamed MARROUCHI \\ Department of English, Sultan ZinalAbidin University, Faculty of Languages and \\ Communication, Terengganu, Malaysia. \\ Mohd Nazri Latiff Azmi \\ Department of English, Sultan ZinalAbidin University, Faculty of Languages and \\ Communication, Terengganu, Malaysia.
}

\begin{abstract}
:
This paper examines the philosophical discourse of the Enlightenment as totalitarian and relativist. This simply means that the subject is a discussion of the way the poststructuralist/ postmodernist thinkers (J.F. Lyotard, M. Foucault, J. Deleuze, J. Derrida, [...] ) write about the Enlightenment thought and modernism compared with the way the supporters of Enlightenment (Jürgen Habermas, Colin Davis, Immanuel Kant [...] ) write about the poststructuralist intellectuals. "Totalitarian ethics" connotes the absolute, classical, logocentric, metaphysical and grand forms of knowledge. However, "relativist politics," refers to the gesture of revising these absolutist ethics by adopting the aesthetics of difference and multiplicity. The assumption is that this discourse is regarded as authoritarian, absolutist and ineffectual since it abuses, betrays, and finally rejects the "other." Accordingly, tow fundamental questions crop up: What sense should be given to the "totalitarian ethics?" In what way can it be argued for the relativist politics of an absolutist discourse? To unmask these blind spots, first, the Enlightenment discourse needs to be addressed in order to discover its most "sublime and metaphysical ideals." Significant consideration is given to Kant and Hegel. Second, the analysis is directed to show how the intellectual trajectory of the postmodern thought devalues, attacks and finally proves that these ethics are "intellectually empty and morally dangerous." To justify this claim, careful attention is paid to J.F Lyotard, J. Derrida, G. Deleuze and M. Foucault. Crystallizing the missed connections between these 'loving paradoxes: absolutism/relativism' reveals the possible, striking and hidden overlaps. In line with the previous findings, the ultimate conclusion the paper draws is that the philosophical discourse of the Enlightenment is totalitarian and relativist as it represents an "unfinished project" of Enlightenment to borrow the term from J. Habermas.
\end{abstract}

Key Words: Enlightenment, postmodernity, philosophical discourse, relativism, totalitarianism

Cites as: MARROUCHI, R. B. M., \& Azmi, M.N.L. (2019). The Philosophical Discourse of the Enlightenment: Totalitarian Ethics or Relativist Politics? Arab World English Journal for

Translation \& Literary Studies, 3 (1) 190- 202.

DOI: http://dx.doi.org/10.24093/awejtls/vol3no1.15 